LAURA LYNN BROWN

\title{
FIFTY THINGS ABOUT MY MOTHER
}

She liked to walk in the neighborhood on summer evenings and would get me to join her by saying, "Let's go look in people's windows."

Linda Lee Gosney was born on October 6, 1938; she died on April 8, 1989, when she was fifty and I was twenty-eight and my brother was twenty-three, between the time she called for my father and the time he made it from his recliner to the bedroom, her mitral valve blown out like a flat tire at high speed, gone in a heartbeat.

Nine months and five days after her wedding, she gave birth to me.

One time when I was sunbathing on the deck and felt something poking me in the hip, I opened my eyes, and there she was with a spatula, deadpanning, "It's time to turn you over."

Once when I was a teen sleeping a Saturday away, she lured me with a cheerful call from the kitchen: "The Red Cross was here and they brought doughnuts."

One morning I took two pretzel sticks from a bowl on the kitchen counter, looked in the bathroom mirror to arrange them like vampire fangs, headed back toward the kitchen with my hands in a scary vampire pose, and met her coming around the corner, her hands in a scary vampire pose, pretzel fangs stuck under her lip.

One Halloween when I was sick, she trick-or-treated for me; another Halloween she dressed up to answer the door and silently handed out candy enshrouded in my red Sears ribcord bedspread and a cheap devil mask; and throughout the year, she would use my brother's astronaut mask, which had a pane of transparent plastic over the eyes, when she was cutting onions.

She had cut from a magazine a particularly startling photo of Richard Avedon-cropped so only half his face, only one raptor eye, was showing- 
and for a while we took turns hiding it for each other to find, until she found an unbeatable place that made me yelp when I found it: under the toilet lid.

She let me read at the dinner table.

She was only slightly exasperated with me the time I got gum stuck in my hair because I had tried storing a chewed piece behind my ear like Violet Beauregarde in Charlie and the Chocolate Factory.

She dealt gently with me when I called my fifth-grade classmate Midge a bitch.

She dealt gently with me when I yelled variations of the F word in the basement with all the fury and frustration I had ever hurled into a single word, not realizing the sound would travel through the ductwork; rather than punishing me-the mortification of having been heard by my grandmother was enough—she wanted to learn what had me so angry.

That time in kindergarten when I was trying to play British with Craig Robson and meant to say "Pip, pip, old chap," but said "Tit, tit" instead, and Craig was worldly enough to know that word and turned me in, she was fascinated to know how I knew British people said that.

For a while she and Craig Robson's mom, Barbara, (neither of whom was fat) and some of the other neighborhood moms rode together to weekly Weight Watchers meetings, and then to lunch.

At the visitation the night before her funeral, I felt helpless dismay and betrayal when I saw a gaggle of church women in the corner, listening to the one who five minutes earlier had asked me what happened, and whose seeming concern for me now looked like gossip-gathering; and I wanted to choke the insurance salesman church member who had done several unethical things to try to get my parents' business and who kept standing there in his plaid sport coat talking, holding up the line of people who wanted to speak to us, unable to see how uncomfortable he was making my father; and I wanted to smite the stranger (who I recently learned was no stranger but my father's Uncle Frank) who thought he was paying a compliment when 
he called my mother's body a beautiful corpse; and I was already weary of church people fishing for more when they said they'd heard I was in DC when she died-was I there on business? — and telling them I was visiting a friend, which was true, although I had also gone for a pro-choice march that weekend, a march that took place while I made the stunned, disbelieving, desperate drive home; so it was a balm and a benediction and a heart-healing kindness when Barbara Robson (who had also gone with Mom and some other moms to Now meetings for a brief season in the 1970s) simply said, "So, you were in Washington," and I simply said yes, and she smiled and said, "I'm glad you were there."

There was a time when my strongest yearning toward heaven was the hope of seeing my mother again.

Hers is the most worn modern Bible I have ever seen, but outside of church I seldom witnessed her reading it.

I never heard her pray.

When I was eleven, after the family had stopped going to church, she started sending me to church camp each summer, and it's been within the last five years that it finally dawned on me that the flicker of something on her face the year I greeted her and Dad at the end of the week with the news "I got baptized!" might have been disappointment that she didn't get to witness a watershed she had probably prayed for.

She sang soprano.

She sang to me when I couldn't sleep: "How Much Is That Doggie in the Window?," and something by Peter, Paul and Mary, and "My Grandfather's Clock," which I would request even though, or perhaps because, it made me cry.

She sang "Hey, Babe, Wanna Boogie?" because she liked John Hartford, whom we had seen in concert at Wheeling College, and because, I think, she knew that the gravity-defying magical realism of the line "We could boogie 
on the ceiling if you think you might be able" (a line she might have made up) thrilled me.

She kept a radio in the kitchen and listened to the Top 40 while she washed dishes, and whenever Michael Martin Murphey's "Wildfire" came on, she would pretend she didn't notice, until the chorus's melisma of "Wi-i-i-i-i-ildfi-ire," which she sang loud and off-key just to annoy me.

She didn't cuss.

She didn't interfere the time Dad beat the breath out of me for something I didn't do.

She didn't spank me ever again after the day she broke a wooden spoon across my backside, the handle still in her hand, the jagged bowl skittering across the linoleum with a cold sound that frightened us both.

The way she expressed anger was to not express it.

When she decided it was time for me to know about sex, she gave me a book for Christmas, The Wonderful Story of How You Were Born.

When she drank-at social events, maybe once a year-she asked for a gin and tonic; at home, her drink of indulgence was Pepsi in her tall mug with the peacock on it, tilted, two ice cubes, the pop poured slowly down the inside.

When she was a bank teller, she was moved up to the second window, the one that got the most traffic.

She built a library of quilting fabric and organized it by hue and tint; she had made several quilts as gifts and was finally working on one for herself.

She loved the ocean, and I think the most joyous I ever saw her was the morning the two of us rented bicycles and explored Rehoboth Beach on what would turn out to be her last summer vacation; and if there is one thing in my life I could go back and do over again, it would be-how to say it? how 
to lay down this beachstone of regret I've carried for twenty-two years? - to not have preferred biking alone the next morning.

My brother's grail quest is to bake an apple pie like Mom's.

She loved going to weekend matinees with the two of us, and she so prized theater naps that after the first time, we were always instructed not to wake her if she fell asleep, which is why she sat through The Empire Strikes Back without ever seeing Yoda.

She liked to stay and watch the credits.

She loved well-made, handcrafted things and warmed her home with pottery, hand-loomed rugs, a Shaker box, all bought at one or another of the arts-andcrafts festivals we went to each year, purchases she often followed by saying, "This will be yours when I kick off."

She won the Bausch \& Lomb science award in high school, as did my brother, who didn't know Mom had won it until we found hers while cleaning out her dresser after she died.

For a few years, after heavy rain or seasonal winds would leave their debris around our corner lot, she wouldn't just tidy the sidewalk; she would sweep our edge of the street.

When I was in graduate school and someone at a social event asked my parents about their children, Dad, the parent who thought compliments went to our heads, said I was a professional student; Mom, the encourager, countered, "Frank thinks everyone who went past the eighth grade is a professional student."

She had learned to drive as a teenager, in a boyfriend's car, but she had let her license lapse and did not drive, though she did all the navigating on trips because it made my father nervous to drive in unfamiliar places.

Her two younger brothers had gone to college, and she was finally going to go that fall to a program at Wheeling College designed for life-seasoned 
students, and when Dad and I went to the mall to get him new shoes for the funeral, we stopped by the salon and canceled the hair appointment she had scheduled so she could have new hair when she picked out glasses at her eye appointment, so she could have a fresh prescription when she took the vision test to get her learner's permit, so I could teach her how to drive the Dodge she had bought a week before she died, so she wouldn't have to rely on anyone to get her to school and back, but in which she had never done more than sit in the driver's seat and imagine where she would go.

In the journal I gave her for what turned out to be her last Christmas, the last entry, three days before she died, is The car's here. That's the first step. Got to save some money fast.

In the mid-1970s she was so impressed by a 60 Minutes piece on Bonnie Consolo, a woman damaged by thalidomide who drove, shopped, and cooked with her feet, that she taught herself to pick things up with her feet-in case she ever lost the use of her hands, she said, but her Mona Lisa smile when she practiced this feat hinted that it was more for the novelty and satisfaction of accomplishing something unnecessary and remarkable.

It's not true that she didn't like to have her picture taken, though one member of my family often says this, based on the fact that she appears in so few; the truth is, she appears in so few because she was usually the one holding the camera.

In our next to last conversation, we quarreled.

She told me sometimes when she was reading - and I think when she said this, she was reading Susan Sheehan's Is There No Place on Earth for Me, or I might have made that up-she would think, "Maybe this is the kind of book Laura will write someday."

Among the accounts with her name on them at the bank, there was a recently opened savings account with a balance of nine dollars.

She asked me several times to read Lonesome Dove by Larry McMurtry, not quite to the point of persistence, not nagging or begging, but with a quiet, 
unspoken pleading - she loved it and she wanted to talk about it with someone she knew would love it too; I had read The Last Picture Show, and I knew I would like the writing enough to ride along with the plot (I understood it was not a Louis L'Amour-type Western), but I didn't, and I'm not sure why; maybe it was just the resistance that even an adult child feels when a parent asks her to do something optional-I could feel her yearning, and maybe that scared or dismayed me in ways I still can't name, or maybe I thought I had too many other "important" things I wanted to read, this being when I was in grad school and had developed a bookaholic habit of acquiring them faster than I could ever read them, a habit that is yet uncured, which is sometimes serendipitous, because on one of the four bookshelves in my bedroom, here is her swaybacked copy, which I still haven't read, but which I've already possessed by writing my name in, and when I finally start reading the first page-such a simple, easy thing to do, no resistance at all—oh God, forgive me, I'm hooked by the first sentence and smitten by a half-sentence in the middle of the second paragraph, "Pigs on the porch just made things hotter," and by the second chapter I understand she probably wanted to talk about the affection the writer bore for these characters, and his attention to their interior lives, which is probably the same reason she begged me to read some Barbara Pym, and now that I've passed fifty myself, maybe by reading this book I can put away the security blanket of regrets and wallow no more in the same pond that made child-me ask for a song I knew would make me cry.

At her funeral, when the preacher began his eulogy, he called her by my name.

The turquoise felt-tip pen I gave her with that journal still writes. 